\title{
Phytoremediation of benzene, toluene, ethylbenzene and xylene contaminated air by $D$. deremensis and $O$. microdasys plants
}

\author{
Mohammad Hossein Mosaddegh ${ }^{1 *}$, Abbas Jafarian ${ }^{2}$, Adele Ghasemi $^{2}$ and Alimohammad Mosaddegh ${ }^{3}$
}

\begin{abstract}
Background: People usually spent about $90 \%$ of their time indoors, which are probably more polluted than outside the buildings. High levels of volatile organic compounds (VOCs) are known as causes of sick building syndrome. The present study was designed to determine the quantitative effects of some plants to improve the quality of the environmental air.

Results: $D$. deremensis and $O$. microdasys were chosen for the present study. There is no report of using $O$. microdasys for cleaning the air from pollutants. So, in this study, the effectiveness of $O$. microdasys in air removing from pollutants was studied and compared with $D$. dermensis.

O. microdasys plant can remove $2 \mathrm{ppm}$ concentration benzene, toluene, xylene and ethylbenzene from air in test chambers completely after 48, 55, 47 and 57 hours, respectively. The removal rates of benzene, toluene, xylene and ethylbenzene (BTEX) from air in the test chambers were $1.18,0.54,1.64$ and $1.35 \mathrm{mg} / \mathrm{m}^{2} \mathrm{~d}^{1}$, respectively.

Conclusions: If an office containing $2.5 \mathrm{ppm}$ of each of BTEX and had an approximate volume of $30 \mathrm{~m}^{3}$, it contains $16,8,22$ and $22 \mathrm{mg} / \mathrm{m}^{3}$ benzene, toluene, xylene and ethylbenzene, respectively. Using ten O. microdasys pots with the same size used in this study, can remove benzene, toluene, xylene and ethylbenzene totally after 36, 40, 30 and 39 hours.

The authors recommended studying the efficiency of the plants for removal of BTEX from air at higher range of concentrations such as 20-30 ppm.
\end{abstract}

Keywords: BTEX, D. deremensis, O. microdasys

\section{Background}

People generally spend about $90 \%$ of their time inside the buildings such as houses, offices and factories (indoor). The indoor air is probably more polluted than that of the outside buildings air (outdoor). Therefore, the possible effects of air pollution on human beings are an international issue [1-4]. Volatile organic compounds (VOCs) are the most important pollutants of indoor air $[4,5]$. Average indoor levels of VOCs may be several times more than that of the outdoor air [6-8]. High levels of VOCs are known as causes of building related illness or sick building syndrome $[5,9,10]$. Several studies have reported the effects of

\footnotetext{
* Correspondence: mopbgmm3@yahoo.co.uk

'Department of Pharmacology and Toxicology, School of Pharmacy and Pharmaceutical Sciences, Yazd Shahid Sadoughi University of Medical Sciences, Yazd, Iran

Full list of author information is available at the end of the article
}

some plants on the improvement of indoor air quality by absorbing air-borne contaminants such as VOCs [11-14].

Staff welfare and productivity were improved by putting plants indoor $[15,16]$. Several indoor plant species have eliminated benzene or hexane at levels of 50 and 150 ppm, respectively [17-19]. These concentrations are several orders of magnitude more than the levels that can be encountered in the indoor air.

It has been showed that one of the VOCs removal agents are microorganisms of the soil. But, there was not significant effect on the VOCs removal for the majority of air contaminants $[18,19]$. Also, it was proven that soil microorganisms can humiliate petroleum hydrocarbons in liquid phase form. Studies such as those conducted by Leigh et al., Margesin et al., and Chaianeau et al. forms the basis of bioremediation [20-22].

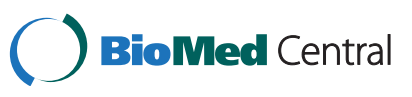


Godish and Guindon reported the effects of spider plants on the removal of formaldehyde up to $50 \%$. They showed that the removal effects of the plants were not primarily via the plants leaves. As they concluded that it must be rather due to other factors such as moisture, soil, microorganisms or all of them [23]. Schmitz et al. studied the effects of 27 indoor plants on the activity of formaldehyde dehydrogenase and formate dehyrogenase. They reported that there was no significant effect on formaldehyde metabolism or uptake from stomata of the plants [24].

Burchett et al. examined the capacity of three plants named Aglaonema modestum, Chamaedoreae legans and Philodendron for cleaning the environment from benzene, toluene, xylene and n-hexane, which are used as industrial solvents for furnishings. They showed that the contaminants concentrations were decreased gradually to below the detection limits of the gas chromatograph $(<20 \mathrm{ppb})$. They found that the pot size in cleaning of the air is in less importance [25].

Reduction of VOCs levels especially in indoor environments is vital to improve human health. So, the present study was designed to determine the quantitative effects of Dracaena deremensis and Opuntia microdasy to improve the quality of the environmental air.

\section{Methods}

\section{Chemicals and supplies}

Benzene, toluene, ethylbenzene, xylene, methanol, acetone and acetonitrile (HPLC grade) were purchased from Merck. All SPME supplies were obtained from Supelco. A CAR/PDMS fiber $(75 \mu \mathrm{m})$ was used for sampling benzene from air. For sampling, EconoGrab 10 L Tedlar Bag with polyproplyene fitting and gas sampling pump (obtained from SKC, UK) were used. The Tedlar bags after each sampling were purged three times with nitrogen for reuse.

\section{Selected plants}

$D$. deremensis and O. microdasys were chosen for the present study. The capability of $D$. dermensis for removing of air pollutants such as benzene and toluene was confirmed by Orwell et al (26). There is no report of using O. microdasys for cleaning the air from pollutants. So, in this study, the effectiveness of O. microdasys in comparison with $D$. dermensis in air removing from pollutants was studied. Three year old plants were transferred to $10 \mathrm{~cm}$ diameter pots. Then, the pots left for two months in the laboratory to get habit with the new conditions. The temperature was kept at $20^{\circ} \mathrm{C} \pm 3$ and the light period was $12 / 12$ hours dark/light. The plants were watered each three days and the remaining water was allowed to drain from the pots. All plants were watered one hour before putting under exposure to gas mixture. The characteristic of the plants are listed in the Table 1.

The plants were placed in the sealed chambers. After an hour, gas treatment was imposed on the plants. The plants with about the same leaf areas were placed in the chambers. Three replicates of each plant were examined for the gas treatment. The empty chambers without plants were tested as control chambers. It was used to determine the losses caused by leakage, chemical reaction or adsorption to the chamber surface. Leaves area of the plants were measured at the end of the test. At the end of each experiment, the plant was extracted from the soil and the pot was placed in the chamber to examine the gas absorption capacity of the soil alone.

\section{Apparatus}

Glass chambers with the internal volume of $0.05 \mathrm{~m}^{3}$ were purchased. Their diameter mouths were $35 \mathrm{~cm}$ that ease putting the pots inside the chamber. Removable glass lids were prepared and sealed with a solvent free adhesive tape. Rubber septa were installed on the centre of the lids for benzene, toluene, ethylbenzene and xylene injection and air sampling. A $2.4 \mathrm{~W}$ fan, controlled with remote, was installed inside the chambers to accelerate atmospheric equilibration. After benzene, toluene, ethylbenzene and xylene loading in the chamber, the fan was turned on for one hour, which is necessary for equilibration. As well, one hour before each sampling the fan was turned on to equilibrate benzene, toluene, ethylbenzene and xylene inside the chamber. Solid phase microextraction (SPME) fiber, CAR/PDMS fiber $(75 \mu \mathrm{m})$, was used for their extraction from the chamber. The fiber was put inside the chamber in contact with the air and left it for equilibration. Then, the fiber was extracted from the chamber and inserted into the injection port for desorption.

Gas chromatography (Younglin series YL 6100) with flame ionization detector was used to determine benzene concentration in the air. A capillary column DB-5MS (J \& W Scientific) fused silica $(60 \mathrm{~m}, 0.25 \mathrm{~mm}$ i.d., $0.25 \mu \mathrm{m}$ film thickness) was used. The operating conditions were: hydrogen flow $30 \mathrm{ml} / \mathrm{min}$., air flow $300 \mathrm{ml} / \mathrm{min}$, helium flow $0.8 \mathrm{ml} / \mathrm{min}$, injector and detector temperatures were $260,280^{\circ} \mathrm{C}$, respectively. The GC oven was held at $40^{\circ} \mathrm{C}$ for $1 \mathrm{~min}$, it was then ramped at $15^{\circ} \mathrm{C} / \mathrm{min}$ to $90^{\circ} \mathrm{C}$ and held for $4 \mathrm{~min}$, and finally ramped at $10^{\circ} \mathrm{C} / \mathrm{min}$ to $170^{\circ} \mathrm{C} / \mathrm{min}$ and held for $4 \mathrm{~min}$. For calibrations, appropriate amounts of benzene, toluene, ethylbenzene and

Table 1 Features of used plants and pots

\begin{tabular}{llll}
\hline Species & Plant age (year) & Leaf area $\left(\mathrm{cm}^{2}\right)$ & Pot diameter $(\mathbf{c m})$ \\
\hline D. deremensis & 3 & $1380 \mathrm{~cm}^{2}$ & 10 \\
O. microdasys & 3 & $1350 \mathrm{~cm}^{2}$ & 10 \\
\hline
\end{tabular}


xylene and methanol (internal standard) were put into a $10 \mathrm{~L}$ Tedlar bag and after equilibration they were extracted using a CAR/PDMS fiber (75 $\mu \mathrm{m}$ film thickness). Standard curves were consistently linear with $\mathrm{R} 2>0.98$. Quantitation was based on peak area ratio, which is relation between their concentrations to methanol concentration.

\section{Procedure}

The plants were watered and left for one hour to drain the extra water. Then, the plants were placed one in each chamber and the lids were sealed by adhesive. Benzene, toluene, ethylbenzene and xylene were added to chambers at final concentration of each $2 \mathrm{ppm}$. The samples were taken from chambers in duplicate and BTEX concentrations were analyzed using a gas chromatograph equipped with flame ionization detector (GC-FID Younglin series YL6100). Calibrations were performed at the BTEX concentrations of $0.2,0.3,0.4,0.5,1,1.5$ and 2 ppm. Samples were taken daily by a CAR/PDMS fiber $(75 \mu \mathrm{m})$ and then immediately were analyzed using GC-FID. At the end of first experiment, the plants were removed and the pots with the soil alone were replaced in the chambers, which were sealed and they were exposed to a new dose of BTEX. For better plant removal, the pots were watered well, and then the plants extracted gently removing as little soil as possible. Finally, the experiment was performed with empty chamber to test the leakage.

\section{Statistical analysis}

Means $(n=3)$ and standard errors (SE) were calculated. Daily BTEX values obtained were subjected to ANOVA analysis. Differences between variables were reported as statically significant where p value was less than 0.05 .

\section{Results and discussion}

Typical calibration curves of benzene, toluene, ethylbenzene and xylene $(n=3)$ in Tedlar bag air are shown in Figure 1. The BTEX concentrations of 0.2-2 ppm were used in these experiments to cover the range corresponding to the values established inside the chambers. Linear relationships between the concentrations of benzene, toluene, ethylbenzene and xyleneand peak area ratio were obtained $\left(r^{2}=0.9936,0.9962,0.9986\right.$ and 0.9956, respectively). BTEX concentrations could be decreased by by chemical destruction, absorption to the chamber and destruction by soil bacteria. To avoid the effects of these factors, the results of the plants were compared with the soil results and the differences between them were significant. Both $D$. deremensis and $O$. microdasys significantly reduced

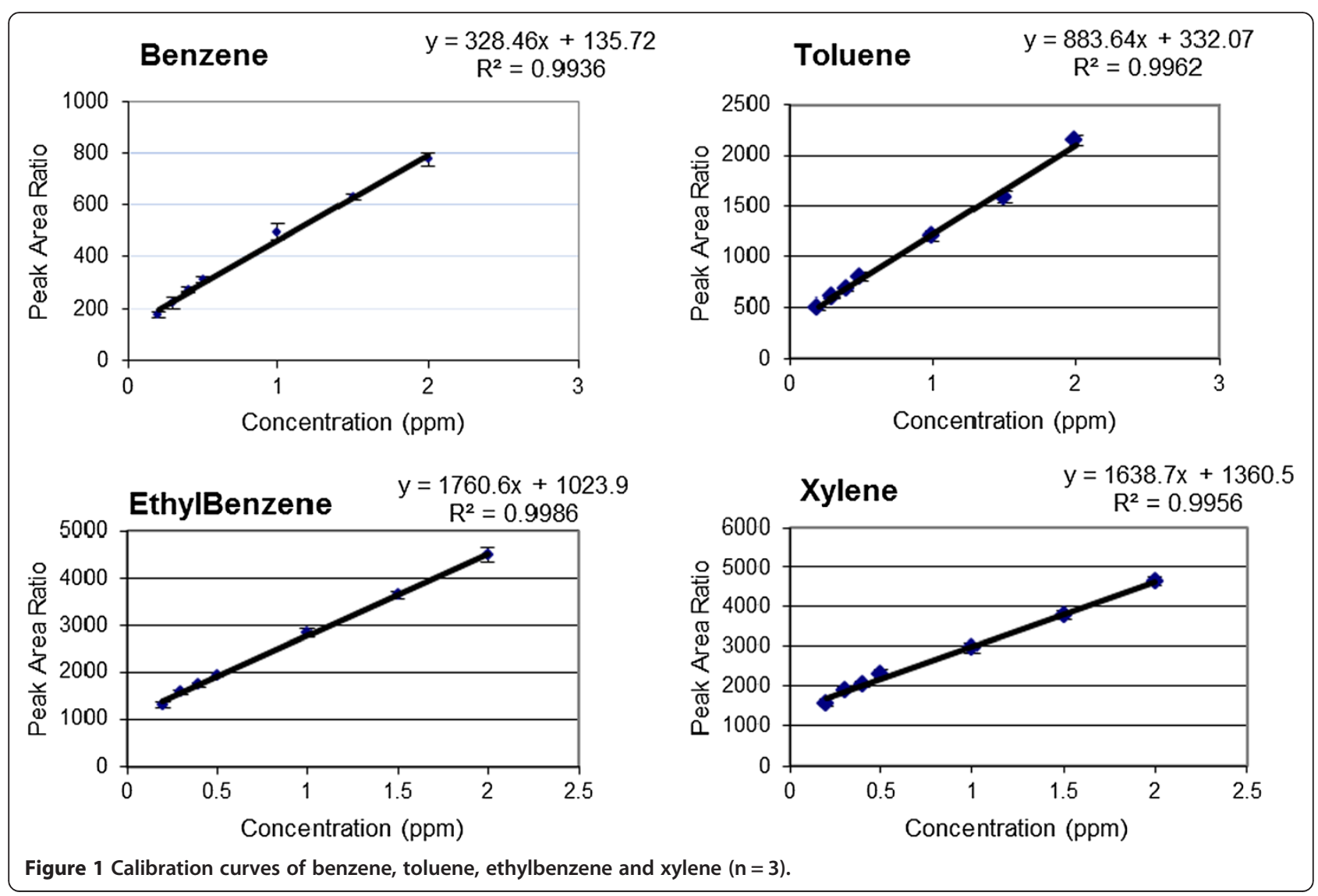




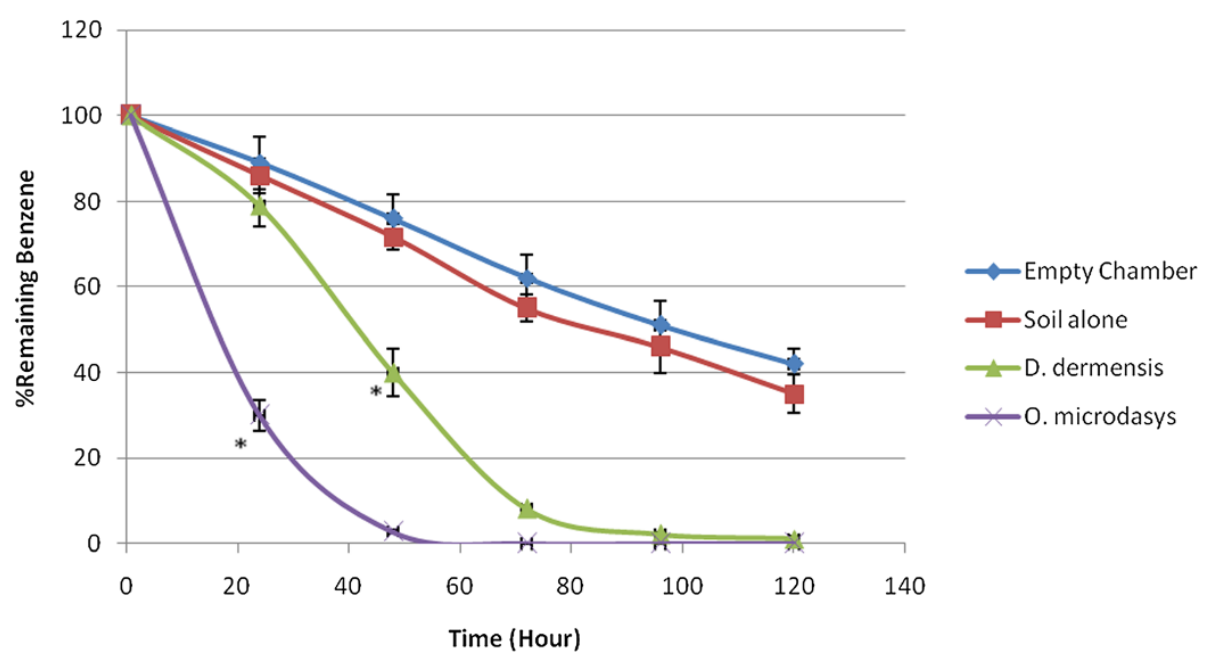

Figure 2 Benzene removal capacity of $\boldsymbol{D}$. dermensis and $\boldsymbol{O}$. microdasys. Benzene concentration was 2 ppm. Data are presented as means \pm $\operatorname{SEM}, \mathrm{n}=3,{ }^{*}=\mathrm{p}<0.05$.

concentration of benzene, toluene, ethylbenzene and xylene in the chambers (Figures 2, 3, 4, 5).

Some of the plants have the capacity to remove air concentrations of VOCs, which knows as phytoremediation. Various plants have different capacities, which in this study the removal ability of the $D$. dermensis and $O$. microdasys plants were expressed based on leaf area, cleaned cubic meter of the air and both of them. Kim et al reported the ability of a few plants to remove volatile substances from indoor area [14].

O. microdasys was able to remove $2 \mathrm{ppm}$ of benzene from air in the test chambers completely after 48 hours. However, $D$. dermensis could remove benzene from air in the test chambers completely after 105 hours. The removal rates of benzene in the test chambers were 3.2 and $1.46 \mathrm{mg} / \mathrm{m}^{3} \mathrm{~d}^{1}$ for $O$. microdasys and D. dermensis, respectively. Also, the removal rates of benzene from air in the test chambers were 1.18 and $0.52 \mathrm{mg} / \mathrm{m}^{2} \mathrm{~d}^{1}$ based on leaf area of $O$. microdasys and D. dermensis, respectively. On the other word, O. microdasys and D. dermensis abilities were 23.2 and $10.6 \mathrm{mg} / \mathrm{m}^{3} \mathrm{~m}^{2} \mathrm{~d}^{1}$, respectively. However, David Moerlein investigated the ability of S. trifasciata, F. robusta, C. seifrizii and D. dermensis in laboratory to reduce total air borne inorganic and organic particles 10 microns or smaller in diameter. The plants did not significantly affect total particles in rooms [26]. Corenjo et al studied the ability of eight species of plants to remove benzene from air. The best removal rate of benzene from air in chamber was $8.5 \mu \mathrm{g} / \mathrm{g}^{1} \mathrm{~d}^{1}$ that removed by the P. Domesticum plant [27]. Their results confirmed the results of present project.

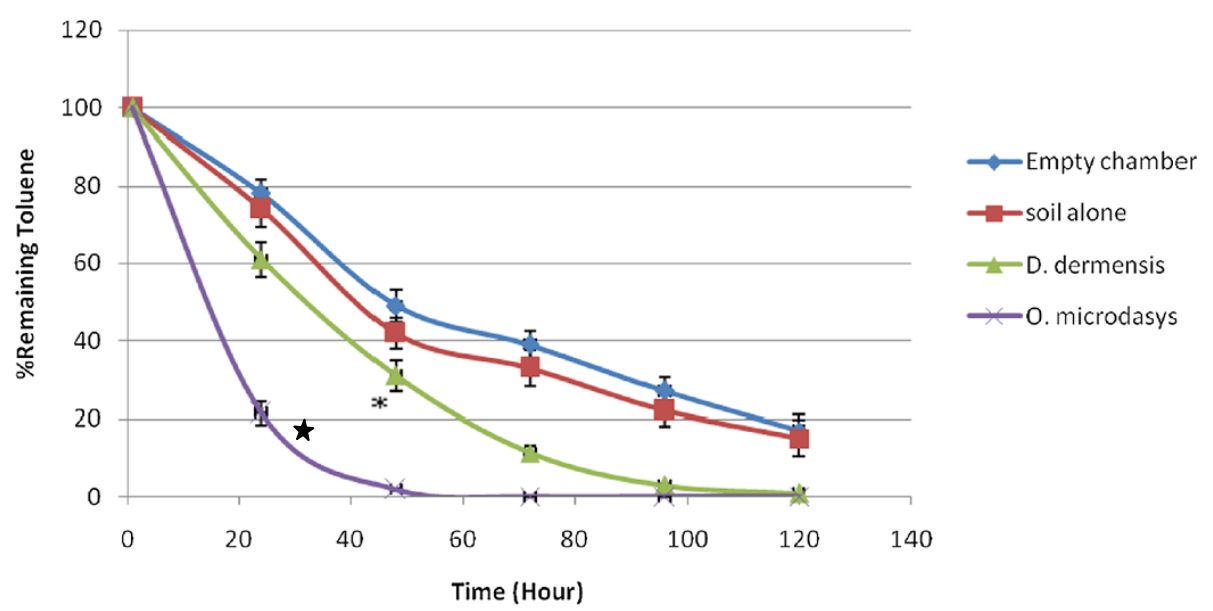

Figure 3 Toluene removal capacity of $\boldsymbol{D}$. dermensis and $\boldsymbol{O}$. microdasys. Toluene concentration was 2 ppm. Data are presented as means \pm SEM, $n=3,{ }^{*}=p<0.05$. 


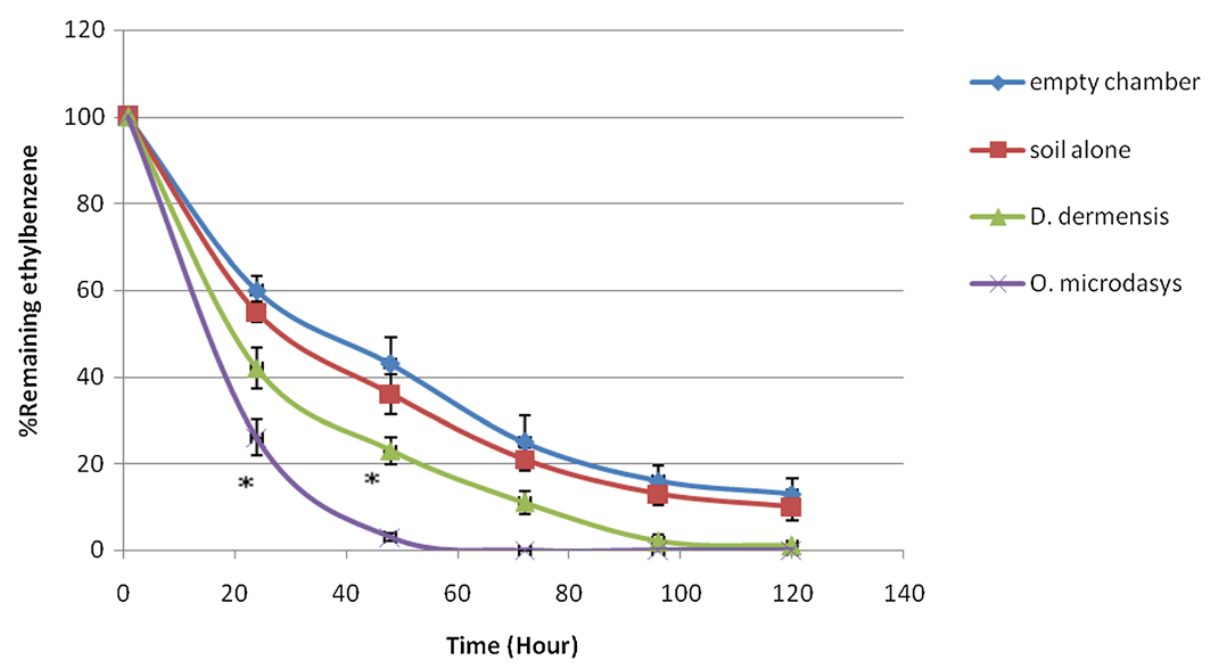

Figure 4 Ethylbenzene removal capacity of $\boldsymbol{D}$. dermensis and $\boldsymbol{O}$. microdasys. Ethylbenzene concentration was 2 ppm. Data are presented as means $\pm \mathrm{SEM}, \mathrm{n}=3,{ }^{*}=\mathrm{p}<0.05$.

O. microdasys was able to remove $2 \mathrm{ppm}$ of toluene from air in the test chambers completely after 55 hours. However, $D$. dermensis could remove toluene from air in the test chambers completely after 120 hours. The removal rates of toluene in test chambers were 1.47 and $0.67 \mathrm{mg} / \mathrm{m}^{3} \mathrm{~d}^{1}$ for $O$. microdasys and D. dermensis, respectively. Also, the removal rates of toluene from air in the test chambers were 0.54 and $0.24 \mathrm{mg} / \mathrm{m}^{2} \mathrm{~d}^{1}$ based on leaf area of $O$. microdasys and $D$. dermensis, respectively. On the other word, O. microdasys and D. dermensis abilities were 10.7 and $4.86 \mathrm{mg} / \mathrm{m}^{3} \mathrm{~m}^{2} \mathrm{~d}^{1}$, respectively. Yang et al used 28 different plant species to determine their removal abilities. They showed that these plants could decrease toluene and benzene concentrations in a closed jar [28]. However, none of these plants had removal ability as much as $\mathrm{O}$. microdasys and $\mathrm{D}$. dermensis plants used in the present study.
Four different plant species were studied by Yoo et al to determine their removal abilities. Their removal abilities for benzene and toluene was good,which confirmed the results of present study [29]. However, their abilities were less than that of $\mathrm{O}$. microdasys and $\mathrm{D}$. dermensis plants.

The removal rates of benzene by the D. Janet Craig, E. aureum, D. marginata, S. amate, S. petite, S. sensation and $\mathrm{H}$. forsteriana were studied by Orwell et al, and they were more than that of $\mathrm{O}$. microdasys and $\mathrm{D}$. dermensis plants [19].

O. microdasys plant can remove $2 \mathrm{ppm}$ concentration xylene from air in test chambers completely after 47 hours. However, D. dermensis can remove xylene from air in test chambers completely after 98 hours. The removal rates of xylene in test chambers are $4.42 \mathrm{mg} / \mathrm{m}^{3} \mathrm{~d}^{1}$ and $2.12 \mathrm{mg} /$ $\mathrm{m}^{3} \mathrm{~d}^{1}$ for $\mathrm{O}$. microdasys and D. dermensis, respectively.

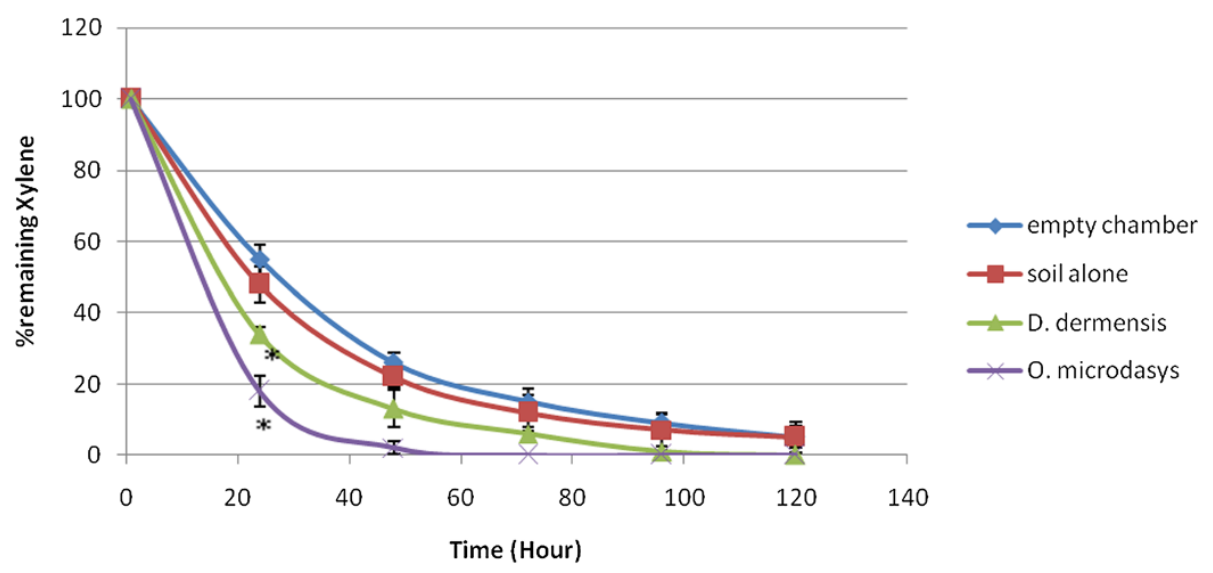

Figure 5 Xylene removal capacity of $\boldsymbol{D}$. dermensis and $\boldsymbol{O}$. microdasys. Xylene concentration was 2 ppm. Data are presented as means \pm SEM, $n=3,^{*}=p<0.05$. 
Also, the removal rates of xylene from air in test chambers are $1.64 \mathrm{mg} / \mathrm{m}^{2} \mathrm{~d}^{1}$ and $0.76 \mathrm{mg} / \mathrm{m}^{2} \mathrm{~d}^{1}$ based on leaf area of O. microdasys and D. dermensis, respectively. On the other word, $O$. microdasys and $D$. dermensis abilities were 32.03 and $15.36 \mathrm{mg} / \mathrm{m}^{3} \mathrm{~m}^{2} \mathrm{~d}^{1}$, respectively. Orwell et al reported the removal ability of S. Sweet Chico and D. Janet Craig plants for toluene and xylene. S. Sweet Chico and D. Janet Craig plants were prior to the plants used in the present study for removing toluene from air. However, the ability of O. microdasys for removing xylene from the air was prior to S. Sweet Chico and D. Janet Craig plants [30].

O. microdasys plant can remove $2 \mathrm{ppm}$ concentration ethylbenzene from air in test chambers completely after 57 hours. However, D. dermensis can remove ethylbenzene from air in test chambers completely after 100 hours. The removal rates of ethylbenzene in test chambers are $3.65 \mathrm{mg} / \mathrm{m}^{3} \mathrm{~d}^{1}$ and $2.1 \mathrm{mg} / \mathrm{m}^{3} \mathrm{~d}^{1}$ for O. microdasys and D. dermensis, respectively. Also, the removal rates of ethylbenzene from air in test chambers are $1.35 \mathrm{mg} / \mathrm{m}^{2} \mathrm{~d}^{1}$ and $0.76 \mathrm{mg} / \mathrm{m}^{2} \mathrm{~d}^{1}$ based on leaf area of $\mathrm{O}$. microdasys and D. dermensis, respectively. On the other word, $O$. microdasys and $D$. dermensis abilities were 26.45 and $15.22 \mathrm{mg} / \mathrm{m}^{3} \mathrm{~m}^{2} \mathrm{~d}^{1}$, respectively.

In authors knowledge, there was not found any study work on the removal of the ethylbenzene so far.

\section{Conclusion}

If an office containing $2.5 \mathrm{ppm}$ of each of BTEX and had an approximate volume of $30 \mathrm{~m}^{3}$, it contains $16,8,22$ and $22 \mathrm{mg} / \mathrm{m}^{3}$ benzene, toluene, xylene and ethylbenzene, respectively. Using ten of O. microdasys pots with the same size used in this study, can remove benzene, toluene, $\mathrm{xy}$ lene and ethylbenzene totally after 36, 40, 30 and 39 hours, respectively.

The authors recommended studying the efficiency of the plants for removal of BTEX from air at higher range of concentrations such as 20-30 ppm.

In conclusion, there are a few studies reported the ability of different plant species in removing organic chemicals from the air. Various plants have different abilities for removal of air borne inorganic and organic particles. The best plant is one with higher removal rate, which could be recommended to be used indoor especially in high air polluted area.

\section{Abbreviations \\ VOCs: Volatile organic compounds; BTEX: Benzene, toluene, xylene and ethylbenzene; SPME: Solid phase microextraction.}

\section{Competing interests}

The authors declare that they have no competing interests.

\section{Authors' contributions}

All authors precipitated in conception and design, generation of data, analysis of data, interpretation of data, drafting of manuscript, revision of manuscript and approval of the final draft.

\section{Acknowledgement}

Authors like to thank Dr Mosaddegh Clinical Toxicology Laboratory for technical support of this project.

\section{Author details}

'Department of Pharmacology and Toxicology, School of Pharmacy and Pharmaceutical Sciences, Yazd Shahid Sadoughi University of Medical Sciences, Yazd, Iran. ${ }^{2}$ Department of Pharmacolgy and Toxicology, School of Pharmacy and Pharmaceutical Sciences, Isfahan University of Medical Sciences, Isfahan, Iran. ${ }^{3}$ School of Pharmacy and Pharmaceutical Sciences, Yazd Shahid Sadoughi University of Medical Sciences, Yazd, Iran.

Received: 29 July 2013 Accepted: 30 November 2013

Published: 22 January 2014

\section{References}

1. Fisk WJ: Review of health and productivity gains from better IEQ. In Proceedings of Healthy Buildings. Helsinki, Finland: Lawrence Berkeley National Laboratory; 2000.

2. Tsai DH, Lin JS, Chan CC: Office workers' sick building syndrome and indoor carbon dioxide concentrations. J Occup Environ Hyg 2012, 9(5):345-351.

3. Weschler $\mathrm{CJ}$ : Chemistry in indoor environments: 20 years of research. Indoor Air 2011, 21(3):205-218.

4. Wolkoff P: Trends in Europe to reduce the indoor air pollution of VOCs. Indoor Air 2003, 13(Suppl 6):5-11.

5. Mendes A, Pereira C, Mendes D, Aguiar L, Neves P, Silva S, Batterman S, Teixeira JP: Indoor air quality and thermal comfort-results of a pilot study in elderly care centers in portugal. J Toxicol Environ Health A 2013, 76(4-5):333-344

6. Rehwagen M, Schlink U, Herbarth O: Seasonal cycle of VOCs in apartments. Indoor Air 2003, 13(3):283-291.

7. Magnusson R, Hägglund L, Wingfors H: Broad exposure screening of air pollutants in the occupational environment of Swedish soldiers deployed in Afghanistan. Mil Med 2012, 177(3):318-325.

8. Zhu X, Jia C: Apportioning variability of polycyclic aromatic hydrocarbons (PAHs) and chlordanes in indoor and outdoor environments. J Environ Monit 2012, 14(7):1926-1934.

9. Carpenter DO: Human health effects of environmental pollutants: new insights. Environ Monit Assessmt 1998, 53:245-258.

10. Wang BL, Takigawa $T$, Takeuchi A, Yamasaki $Y$, Kataoka H, Wang DH, Ogino $\mathrm{K}$ : Unmetabolized VOCs in urine as biomarkers of low level exposure in indoor environments. J Occup Health 2007, 49(2):104-110.

11. Wolverton BC, Wolverton JD: Plants and soil microorganisms: removal of formaldehyde,ethylbenzene, and ammonia from the indoor environment. Journal of Mississippi Academic Science 1993, 38(2):11-15.

12. Giese M, Bauer-Doranth U, Langebartels C, Sandermann H Jr: Detoxification of formaldehyde by the spider plant (ChlorophytumcomosumL.) and by soybean (Glycine max L.) cell-suspension cultures. Plant Physiol 1994, 104:1301-1309.

13. Agrawal M, Singh B, Rajput M, Marshall F, Bell JN: Effect of air pollution on peri-urban agriculture: a case study. Environ Pollut 2003, 126(3):323-329.

14. Kim KJ, Kil MJ, Song JS, Yoo EH: Efficiency of volatile formaldehyde removal by indoor plants: contribution of aerial plant parts versus the root zone. Hortscience 2008, 133(4):521-526.

15. Levy Jl, Clougherty JE, Baxter LK, Houseman EA, Paciorek CJ: Evaluating heterogeneity in indoor and outdoor air pollution using land-use regression and constrained factor analysis. Res Rep Health Eff Inst 2010, 152:5-80.

16. Lu CY, Ma YC, Lin JM, Li CY, Lin RS, Sung FC: Oxidative stress associated with indoor air pollution and sick building syndrome-related symptoms among office workers in Taiwan. Inhal Toxicol 2007, 19(1):57-65.

17. Song JE, Kim YS, Sohn JY: The impact of plants on the reduction of volatile organic compounds in a small space. J Physiol Anthropol 2007, 26(6):599-603.

18. Wood RA, Orwell RL, Tarran J, Torpy F, Burchett M: Potted-plant/growth mediainteractions and capacities for removal of volatiles from indoor air. Journal of Horticultural Science and Biotechnology 2002, 77(1):120-129.

19. Orwell RL, Wood RA, Tarran J, Torpy F, Burchett MD: Removal of benzene by the indoor plant/substrate microcosm and implications for air quality. Water Air Soil Pollut 2004, 157:193-207. 
20. Leigh MB, Fletcher JS, Nagle DP, Prouzova P, Mackova M, Macek T: Field evidence of rhizosphere enrichment of PCB-degrading bacteria. Abs Gen Meet Amer Soc Microbiol 2003, 103:117.

21. Margesin R, Gander S, Zacke G, Gounot AM, Schinner F: Hydrocarbon degradation and enzyme activities of cold-adapted bacteria and yeasts. Extremophiles 2003, 7(6):415-458.

22. Chaianeau CH, Rougeux G, Ye-premiain C, Oudot J: Effects of nutrient concentration on the biodegradation of crude oil and associated microbial populations in the soil. Soil Biol Biochem 2005, 37(8):1490-1497.

23. Godish T, Guindon C: An assessment of botanical air purification as a formaldehyde mitigation measure under dynamic laboratory chamber conditions. Environ Pollut 1989, 61:13-20.

24. Schmitz $H$, Hilgers $U$, Weidner M: Assimilation and metabolism of formaldehyde by leaves appear unlikely to be of value for indoor air purification. New Phytol 2000, 147:307-315.

25. Burchett M, Torpy F, Tarran J: Interior plants for sustainable facility ecology and workplace productivity. In Proceedings of HMAA Conference. Queensland Australia: Faculty of Science, University of Technology; 2008:7-9.

26. Moerlein D: Reduction of harmful air pollution: potential ability of different plant species to remove particulate matter from indoor air. MSC Thesis. Cincinnati: University of Cincinnati; 2005.

27. Cornejo JJ, Munoz FG, Ma CY, Stewart AJ: Studies on the Decontamination of Air by Plants. Ecotoxicology 1999, 8:311-320.

28. Yang DS, Pennisi SV, Kays SJ: Screening Indoor Plants for Volatile Organic Pollutant Removal Efficiency. Hort Sci 2009, 44(5):1377-1381.

29. Yoo MH, Kwon YJ, Son K: Efficacy of indoor plants for the removal of single and mixed volatile organic pollutants and physiological effects of the volatiles on the plants. J Amer Soc Hort Sci 2006, 131(4):452-458.

30. Orwell R, Wood R, Burchett M, Tarran J, Torpy F: The potted-plant microcosm substantially reduces indoor air voc pollution: II. Laboratory study. Water, air and soil pollution 2006, 177:59-80.

doi:10.1186/2052-336X-12-39

Cite this article as: Mosaddegh et al.: Phytoremediation of benzene, toluene, ethylbenzene and xylene contaminated air by $D$. deremensis and O. microdasys plants. Journal of Environmental Health Science \& Engineering 2014 12:39.

\section{Submit your next manuscript to BioMed Central and take full advantage of:}

- Convenient online submission

- Thorough peer review

- No space constraints or color figure charges

- Immediate publication on acceptance

- Inclusion in PubMed, CAS, Scopus and Google Scholar

- Research which is freely available for redistribution 